Research Article

\title{
Influence of Shape and Size of Foundation on Vibration Reduction of High-Speed Punching Press Based on Multidomain Modeling
}

\author{
Teng Xu $\mathbb{D},{ }^{1,2}$ Qinxiang Xia $\mathbb{D}^{\mathbb{D}},{ }^{3}$ Xiaobin Long, ${ }^{4}$ Jiaqi Ran, ${ }^{1}$ and Feng Gong ${ }^{1}$ \\ ${ }^{1}$ Guangdong Provincial Key Laboratory of Micro/Nano Optomechatronics Engineering, Shenzhen University, \\ No. 3688 Nanhai Avenue, Nanshan District, Shenzhen 518060, China \\ ${ }^{2}$ National Engineering Research Center of Near-Net-Shape Forming for Metallic Materials, South China University of Technology, \\ Guangzhou 510640, China \\ ${ }^{3}$ Guangdong Provincial Key Laboratory of Precision Equipment and Manufacturing Technology, \\ School of Mechanical and Automotive Engineering, South China University of Technology, Guangzhou 510640, China \\ ${ }^{4}$ OMS Machinery Co., Ltd., Zhongshan, China
}

Correspondence should be addressed to Qinxiang Xia; meqxxia@scut.edu.cn

Received 7 August 2020; Revised 15 September 2020; Accepted 29 September 2020; Published 21 October 2020

Academic Editor: Traian Mazilu

Copyright $\odot 2020$ Teng Xu et al. This is an open access article distributed under the Creative Commons Attribution License, which permits unrestricted use, distribution, and reproduction in any medium, provided the original work is properly cited.

With the aid of multidomain modeling method, the vibration of a high-speed punching press was modeled and predicted, and the influence of the installation of foundation, as well as the shape and size parameters of the foundation on the vibration of the punching press, is discussed. The rectangular foundation size with the best effect of vibration reduction under the premise of saving the installation area was obtained. The validity of the multidomain model of the high-speed punching press with the foundation for vibration reduction is verified, by comparing the simulation results with the experimental results.

\section{Introduction}

For the continuous improvement of the production efficiency demand of enterprises, the stamping speed and the mechanism inertia force of high-speed punching press gradually increase [1], resulting in serious vibration among the high-speed punching pressing, thus reducing the stamping quality [2]. Even very slight vibration of the punching press would lead to forming defects during the stamping process; the vibration problem would not only pose a great threat to the accuracy and service life of the punching press and stamping die but also bring vibration and noise pollution to the working environment of stamping workshop and the living environment around the factory. The sensitivity of the punching press operator's hearing organ would also be decreased greatly by the vibration and noise pollution, which is easy to cause safety accidents $[3,4]$. Due to the restriction of vibration problem, the stroke frequency of the punching press for fin part manufacturing could not be increased greatly, most of which are only about 200 times/min, and the production efficiency has been limited seriously. It is helpful to improve the service performance and life of punching press through the research on vibration prediction and vibration reduction of which, and therefore, the forming accuracy and production efficiency could be greatly improved.

According to the disciplines and theories involved in each part, complex electromechanical products can be divided into different subsystems, such as mechanical system, control system, and electronic system. The vibration problem of punching press system is closely related to the mechanical, foundation, control, electronic, hydraulic, and other subsystems of its organic whole. Among these, the installation of the foundation is helpful to increase the base weight of the punching press system, so as to change the stiffness and damping of the soil layer under the foundation 
and finally reduce the vibration of the punching press. Based on the numerical simulation of the working performance and operating condition of the punching press, the adjustment of the structure and size parameters of the foundation could be carried out according to the simulation results; therefore, the vibration problem of the punching press can be reduced.

At present, the foundation-based simulation research for punching press and other equipment are mostly focused on single domain simulation; that is, according to the theoretical knowledge of subsystems that need attention, special software in different fields would be selected to carry out simulation research on the characteristics of that subsystems, and then, these simulation results of each subsystem be integrated and exploded as a whole. Xue et al. [5] monitored the serious vibration of a steam turbine and blower and put forward the vibration reduction measures of installing vibration isolation rubber pad and spring damper under the foundation and platform. Liu et al. [6] measured the vibration of a stone cutter and summarized that the serious vibration was caused by the poor connection stiffness of the components, and the influence of the pile body concrete and its friction coefficient on the dynamic stiffness of the structure was also explored. Zhu and Chen [7] explored the vibration problem of frame foundation of a turbo generator unit, the on-site vibration response monitoring and analysis of the foundation under different operating conditions were carried out, and the feasibility of the vibration reduction measure using spring damping was verified by comparing the dynamic response results before and after the installation of the damping foundation. Xia et al. [8] established a finite element model of a high-precision equipment adopting vibration isolation; with the aid of the finite element software ANSYS, the vibration attenuation curve was obtained based on the least square regression analysis, and the results turned out that better vibration isolation effect can be obtained by the reasonable selection of the location, depth, and length of the vibration isolation ditch. Zhang et al. [9] explored tangential dynamic behaviors of the machine hydrostatic slide with a magnetorheological (MR) fluid damper and discussed the effect of the MR damper to control the vibration of the hydrostatic slide, the result turned out that the dynamic response of the machine hydrostatic slide with the MR damper is discussed, and it is verified that the MR damper can suppress the tangential vibration of the hydrostatic slide effectively and the constant controller can control the chaotic behavior of the system well. Zeng et al. [10] investigated vibration behaviors of two kinds of lowvibration track (LVT) systems for heavy-haul railway, two indoor full-scale low-vibration track models were constructed according to design drawings, the frequency-domain distribution was analyzed, the vibration reduction performance was evaluated, and the results show the new LVT has lower vibration acceleration, shorter duration of vibration period, lower vibration frequency of track components, and most importantly an obvious vibration reduction effect on the ground. However, low simulation efficiency as well as integration analysis deviation usually exist during the single domain simulation. Besides, these researches mentioned above mostly focus on theoretical analysis and trial and error exploring the dynamic machine vibration reduction of foundation design. Nowadays, there are few simulations and experimental studies on the influence of foundation structure and size on the vibration reduction effect of dynamic machine.

Multidomain modeling method is a simulation study which combines different disciplines theory and models in the same simulation environment and considers the influence of each domain model parameter on the whole system. It can greatly improve the simulation efficiency and avoid the numerical integration error caused by the information exchange between the models established by professional software in different fields $[11,12]$.

In this paper, a precision high-speed punch is taken as the research object. On basis of the multidomain modeling and simulation, influence of the installation of foundation system on vibration reduction effect was studied, and the influence law of block shape and size parameter of the foundation on vibration reduction effect was explored.

\section{Multidomain Modeling of High-Speed Punching Press}

2.1. Structure of High-Speed Punching Press. The research object in this paper is a high-speed punch with the overall type closed four-point structure, as shown in Figure 1 [12], which is used to stamp air conditioning heat exchange fins. The stamping frequency for manufacturing of fins can reach 300 times/minute, and the corresponding motor speed can be as high as $1500 \mathrm{rpm}$. Structure of the fins manufactured by the punching press is shown in Figure 2, and the fin part is stamped by aluminum foil with a thickness of $0.115 \mathrm{~mm}$, with the help of 13 stations' progressive stamping die. The formation involves multiple stamping processes such as drawing, punching elliptical hole, and flanging, and the tolerance of hole, hole distance, and flanging height of the fin parts is $\pm 0.02 \mathrm{~mm}$; therefore, the high operation accuracy of the punching press is required [13].

\subsection{Multidomain Modeling and Simulation of High-Speed} Punching Press. The signal- and physical object-oriented modeling method based on SimulationX was adopted to establish the multidomain model of the punching press (as shown in Figure 3), according to the structure and vibration characteristics. The control system, servo motor, inertia block and inertia database, displacement sensor, and other mechanism components were included in the multidomain model, and the corresponding damping and stiffness coefficients of the bed base, drive screw, and connecting rod were also set.

The multidomain simulation of the situation when the high-speed punching press was placed on the floor of the workshop without foundation is carried out, as shown in Figure 4. In this paper, the high-speed punching press was directly placed on the cement floor of the workshop through the cast iron adjustment block, and thickness of the cement floor was $50 \mathrm{~mm}$, under which was the natural soil layer. 


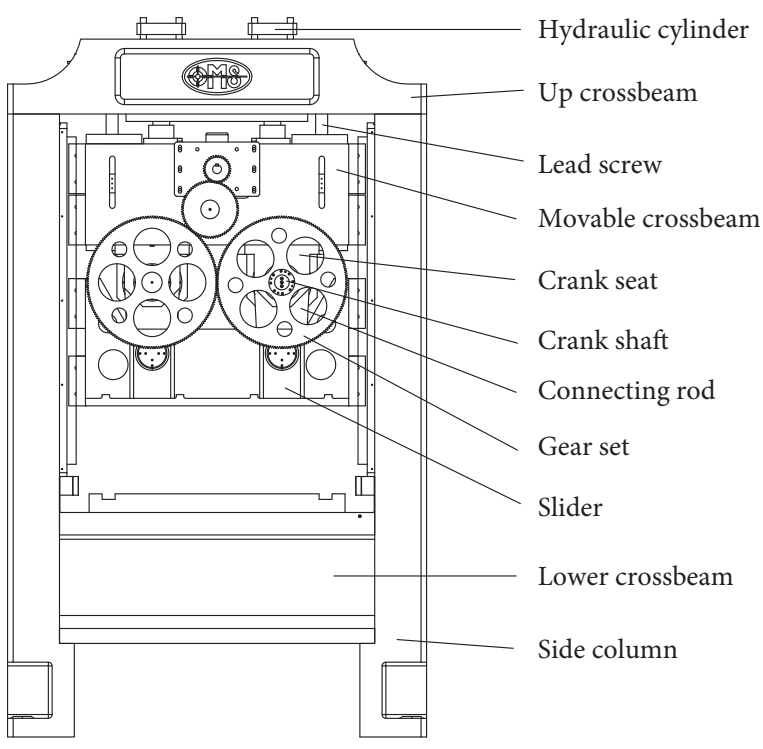

FIGURE 1: High-speed precision servo punching press.

Figure 4 shows the displacement-time curves of the slider and frame; under the condition of stamping, the equilibrium position of the reciprocating motion of the slider was $-22.753 \mathrm{~mm}$, and the amplitude of the motion was $21.117 \mathrm{~mm}$. The frame vibrated with an amplitude of $1.177 \mathrm{~mm}$, at an equilibrium position of $-2.812 \mathrm{~mm}$ under the condition of stamping. According to the above results, the relative distance between the equilibrium positions and the difference in amplitude of the slider and frame can be calculated as 0.059 and $0.060 \mathrm{~mm}$, respectively, and the relative vibration between the frame and slider under the condition of stamping was $0.119 \mathrm{~mm}$, which was larger than the thickness of the workpiece of the heat exchanger fin $(0.115 \mathrm{~mm})$. Therefore, the working performance of punching press needs to be further improved.

\section{Influence of the Foundation Installation on Effect of Vibration Reduction}

Installation of the foundation is critical for adjusting the stiffness and damping parameters of the soil under the punching press, reducing the vibration of the punching press so as to improve the punching accuracy [14]. In this paper, the vibration of high-speed punching press under the situation before and after the installation foundation is studied by means of multidomain modeling and simulation method. Based on the simulation results, the influence law of the foundation size on the effect of vibration reduction is analyzed to guide the design of foundation size.

According to the previous experience of foundation design $[15,16]$, an integral block foundation for punching press was designed, as shown in Figure 5, with a size of $2.8 \mathrm{~m} \times 2.8 \mathrm{~m} \times 1.4 \mathrm{~m}$. The bottom layer of the foundation was concrete, and the main layer was composed of concrete with the scale of $1: 1.5: 3$. The foundation bolt was installed in the main layer of the secondary poured concrete to connect the punch base, and the total depth of the foundation was $1.40 \mathrm{~m}$. For the reason that the anchor screw and shockproof pad shown in Figure 5 only account for very small part, components of the foundation were set as a whole rigid body, during the establishment of the multidomain model of the punching press system. The No. 150 concrete was adopted to build the foundation, and the density of which was $2400 \mathrm{~kg} / \mathrm{m}^{3}$ [17].

Based on the multidomain simulation of operation performance of high-speed punching press with the subdomain of foundation, the displacement-time curves of the slider and frame, under the condition of stamping, was obtained, as shown in Figure 6. The frame vibrated with an amplitude of $0.457 \mathrm{~mm}$ at an equilibrium position of $-2.660 \mathrm{~mm}$ under the condition of stamping. The equilibrium position of the reciprocating motion of the slider was $-22.632 \mathrm{~mm}$, and the amplitude of the motion was $20.453 \mathrm{~mm}$. According to the above results, the relative distance between the equilibrium positions and the difference in amplitude of the slider and frame can be calculated as 0.028 and $0.004 \mathrm{~mm}$, respectively, and the relative vibration between the frame and slider under the condition of stamping was $0.032 \mathrm{~mm}$, which was far less than $0.115 \mathrm{~mm}$, the thickness of the fin part. After the installation of the foundation, rigidity of the soil at the bottom of foundation could be greatly improved [18], and the relative vibration between the slider and frame was reduced from $0.119 \mathrm{~mm}$ to $0.032 \mathrm{~mm}$ and decreased by $73 \%$.

\section{Experimental Verification}

Based on the results of multidomain simulation of the precision high-speed servo CNC punching press in this paper, the experimental operation of which was carried out. The acceleration value of the components of the servo punch under the no-load condition of $1000 \mathrm{rpm}$ motor speed was measured by dh5923 dynamic signal test and analysis system (as shown in Figure 7), and the vibration displacement curve of the frame and slider was obtained by integration. E6cp photoelectric sensor was adopted to measure the rotation speed of the crankshaft in high-speed punch [19], as shown in Figure 8. The correctness of the multidomain modeling could be verified by comparing the simulation results and the experimental results.

Figure 9 shows the simulated and experimental measured curve of the displacement curves of the slider and the frame with the motor speed of $1000 \mathrm{rpm}$. As shown in Figure 9(a), the experimental amplitude of the slider was $20.966 \mathrm{~mm}$ and the simulated value of which was $20.693 \mathrm{~mm}$, with a relative error between which was $1.30 \%$. As shown in Figure 9(b), the vibration amplitude of the frame is $0.812 \mathrm{~mm}$, and the simulated value of that was $0.695 \mathrm{~mm}$, with a relative error of $14.41 \%$.

Figure 10 shows the experimental and simulated rotation curves of crankshaft under the condition that the motor speed was $1000 \mathrm{rpm}$. The theoretical rotation speed is $200 \mathrm{rpm}$, and the experimental rotation speed fluctuated between $194 \mathrm{rpm}$ and $206 \mathrm{rpm}$. As shown in Figure 10(a), the fluctuation of the experimental amplitude was $12 \mathrm{rpm}$. The simulated rotation speed of the crankshaft fluctuated 

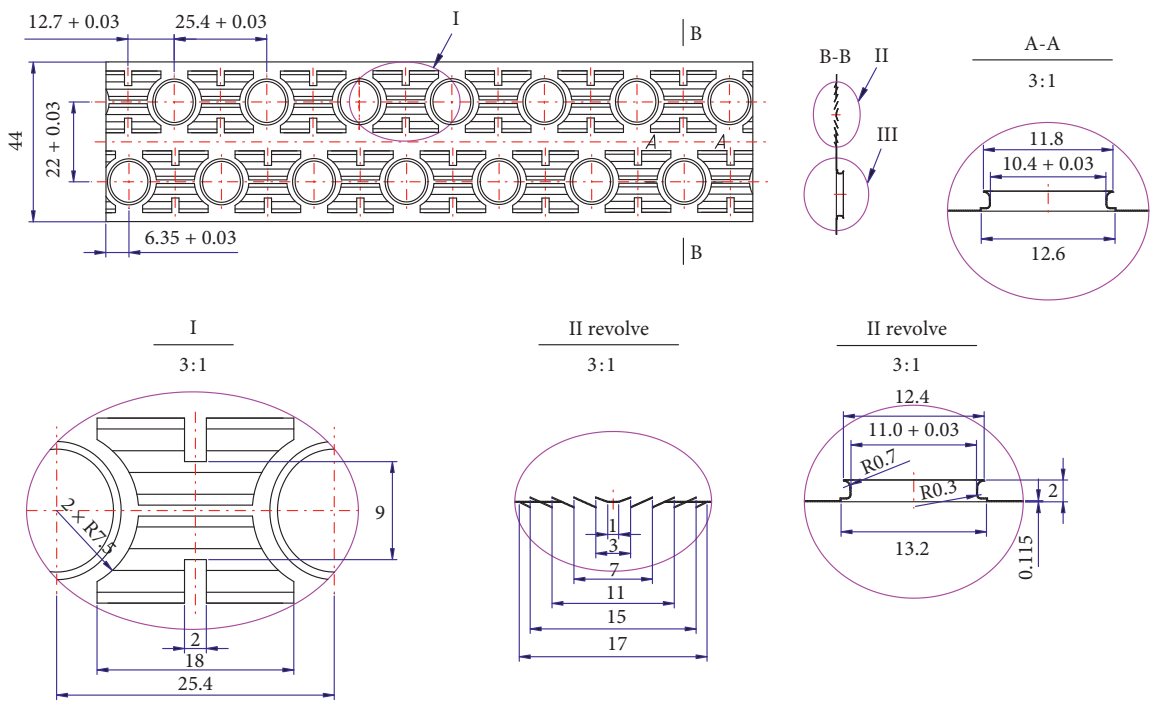

Figure 2: Heat exchanger fin.

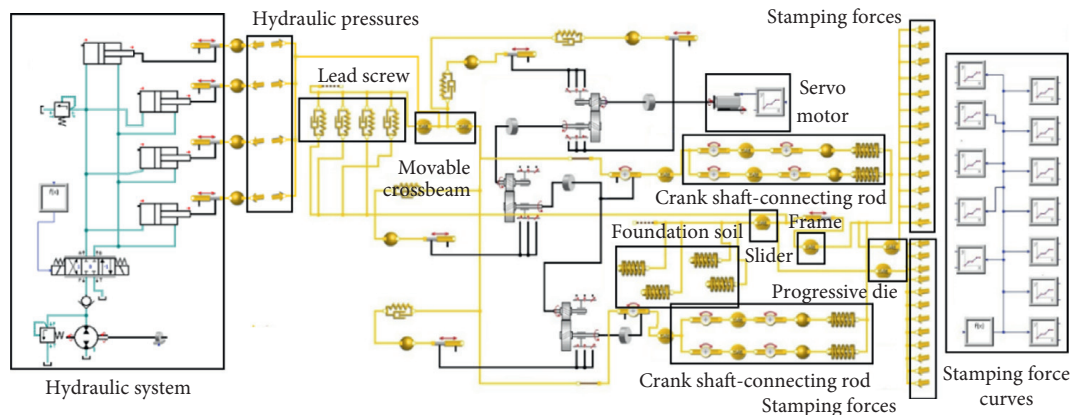

(a)



(b)

FIGURE 3: Multidomain model of high-speed punching press: (a) component structure of multidomain model of punching press; (b) 3D view of multidomain model.

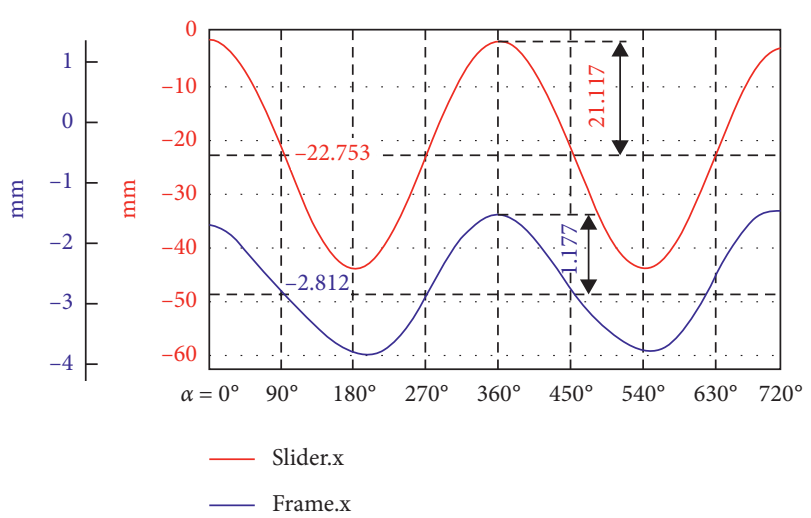

FIGURE 4: Displacement curves of the frame and slider without the installation of foundation.

between $196 \mathrm{rpm}$ and $204 \mathrm{rpm}$, as shown in Figure 10(b). The maximum relative error between the theoretical value and the experimental value is $6 \%$, and the fluctuation amplitude is $8 \mathrm{rpm}$.

\section{Influence of Foundation Size on Effect of Vibration Reduction}

5.1. Selection of Foundation Dimension Groups of Punching Press. As mentioned before, the installation of foundation will increase the quality of basis group of the punching press system, as well as increase its acting area on the soil under the foundation; therefore, the rigidity and damping of the soil would be changed, resulting in the vibration reduction of the punching press. The vertical projection of the structure of the punching press is rectangular, while the foundation designed was square, as shown in Figure 5, which is considered to be detrimental to saving the installation area. Several groups of foundations with different sizes were designed, and the vibration of the punching press with the foundations in different sizes was compared to obtain the influence rule of foundation size on effect of vibration reduction, furthermore to achieve better vibration reduction effect and better installation area by changing the foundation size. The rectangular foundation with different sizes was designed by increasing the length and width of the vertical 


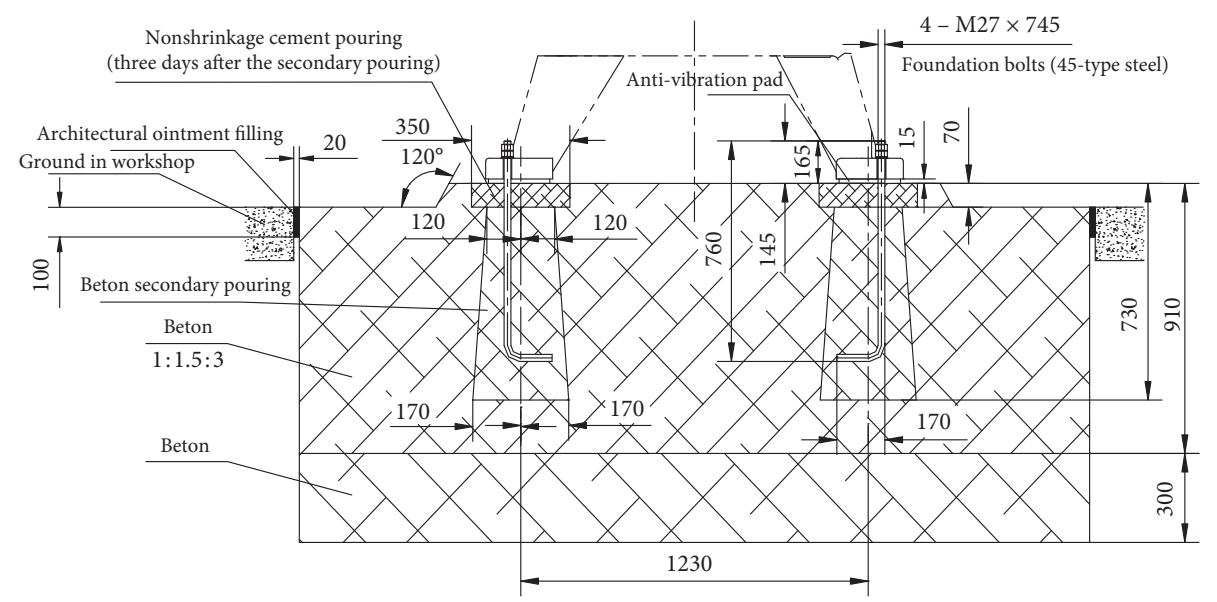

Figure 5: Foundation of punching press.
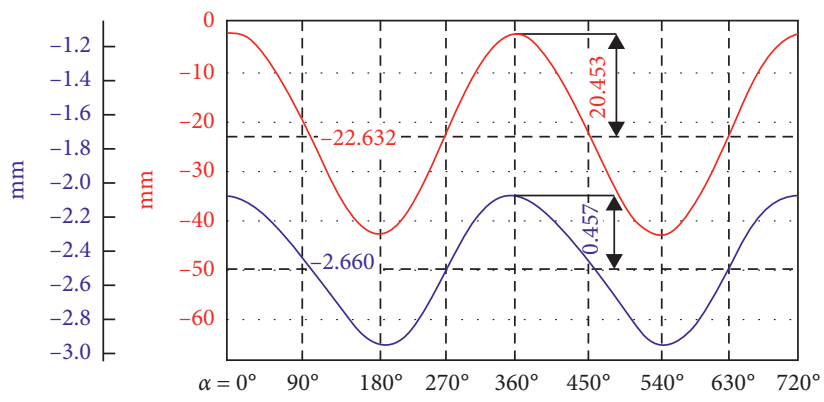

Figure 6: Displacement curves of the frame and slider under the condition of stamping.

projection of the punch by the same size, according to the foundation design specifications, as shown in Table 1. The minimum mass of the foundation was determined as the mass of the punch; according to the relationship between the mass of punching press system and the bearing mass of the soil under the foundation, the minimum value of the length and width of the foundation bottom was calculated as $2.25 \mathrm{~m} \times 3.11 \mathrm{~m}[20,21]$. According to the obtained rectangular foundation dimensions, the square and circular foundation dimensions with the same bottom area and depth are derived, as shown in Table 1.

Based on the design of the shape and size of foundation, multidomain models of punching press with different foundations were established, and multidomain simulation of the vibration on the punching press under different conditions was carried out to make a comparative study, as shown in Figure 11.

5.2. Influence of Foundation Depth on Vibration Reduction. The vibration of high-speed punch after the installation of foundations in different shapes with the same bottom area and different buried depths, based on multidomain simulation, is shown in Table 2. In this paper, the relative vibration quantity of the punching press was considered as the summation of the amplitude differences of the frame and slider and the relative distance between the equilibrium positions of the frame and slider. It can be seen from Table 2 that, when the bottom area and depth of the foundation were the same, the reorder of vibration quantities was corresponding to the foundation of different shapes as follows: rectangle $<$ square $<$ circle. This is because the projection of the punching press on the ground is rectangle, for different shapes foundation with the same depth and bottom area, and the constraint of the rectangular foundation on the outer contour of the punching press is more significant.

For the reason that the damping of soil is inversely proportional to the square root of the mass of the basis group of the punching press, as shown in formula (1) $[21,22]$, as shown in Table 2, the corresponding stiffness of the soil remains unchanged, while the damping decreases when the foundation depth increases; therefore, the amplitude of the frame and the slide increase with the decrease in the damping of the soil, as shown in Table 2:

$$
\zeta_{z}=\frac{0.16 \sqrt{\rho A \sqrt{A}}}{\sqrt{m_{B}}}
$$

where $\rho$ is the density of soil under the foundation and $a$ is the bottom area of the foundation.

As shown in Table 2, with the increase in depth of the foundation, the amplitude of the slide and the frame increased, for the reason that damping of the soil decreases with the increasing depth of foundation. With the increase in the depth, the mass of the base group of the punching press increases, and the energy for maintaining the vibration increases. However, the vibration difference between the slide and the frame decreases gradually, so the relative vibration quantity of the frame and the slide decreases with the increasing foundation mass. The increase in the depth increases the difficulty in the installation of foundation, which cannot be increased infinitely.

\subsection{Influence of Foundation Area on Vibration Reduction.} The vibration amounts of punching press corresponding to a series of foundations with the same depth and varying bottom area obtained from multifield simulation are shown 


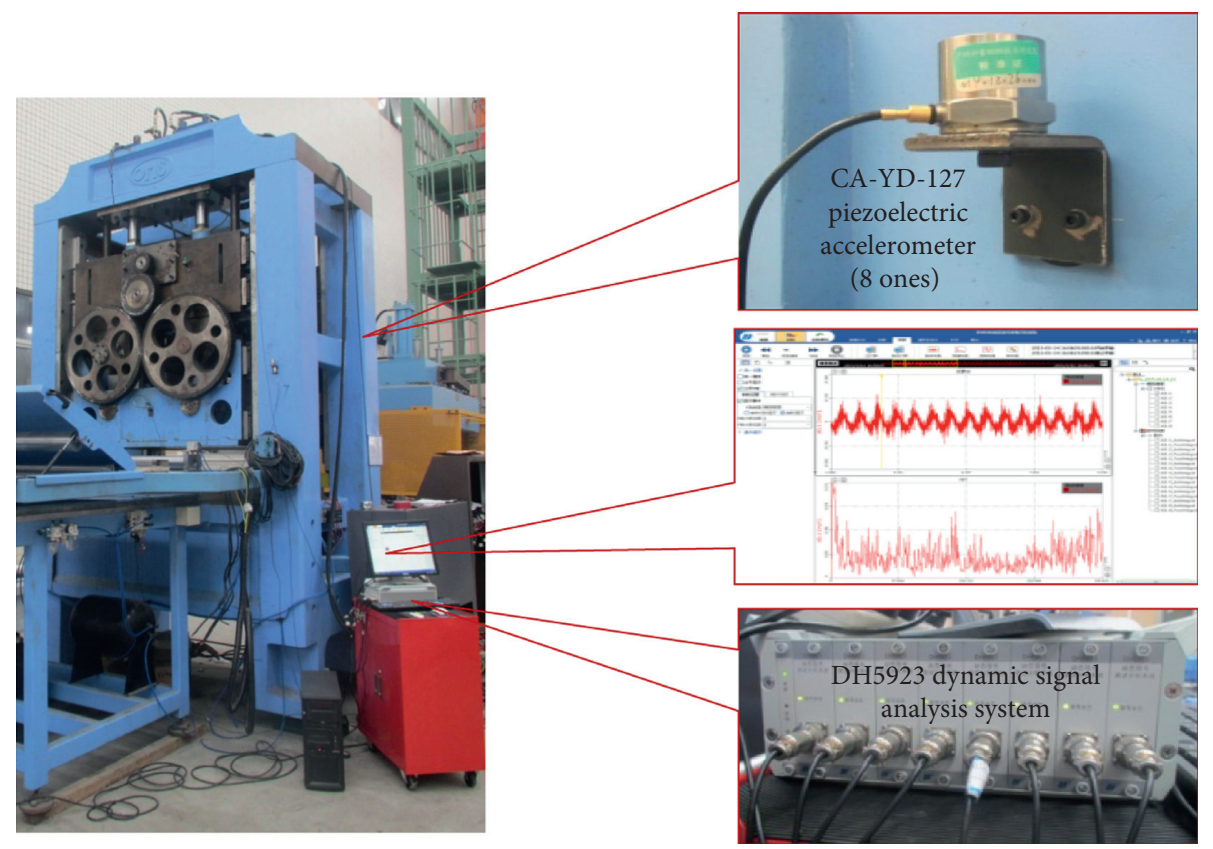

Figure 7: Acceleration test experiment of main parts.

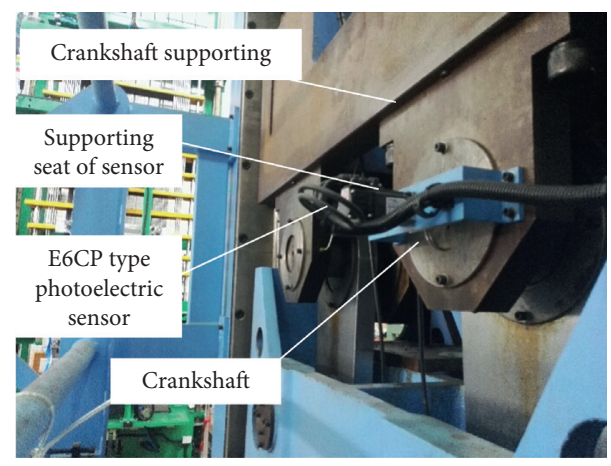

FIgURE 8: E6CP photoelectric speed sensor measuring tool.

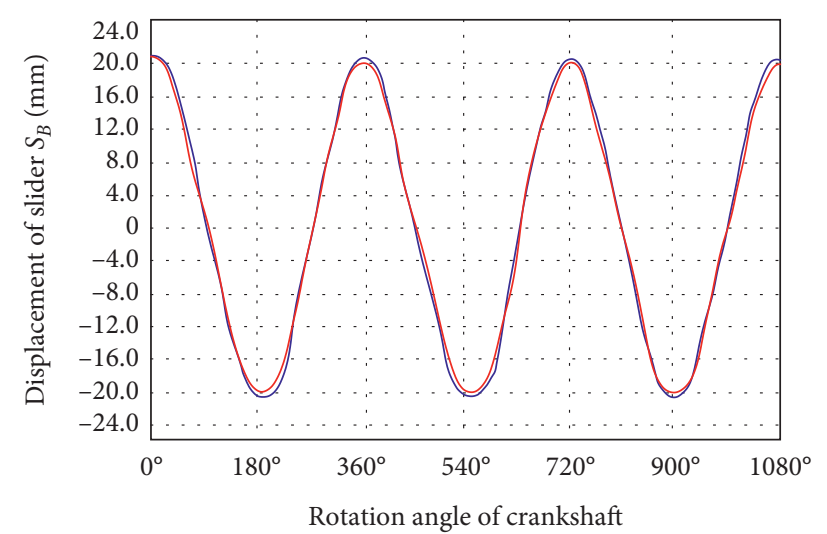

- Experimental

— Simulated

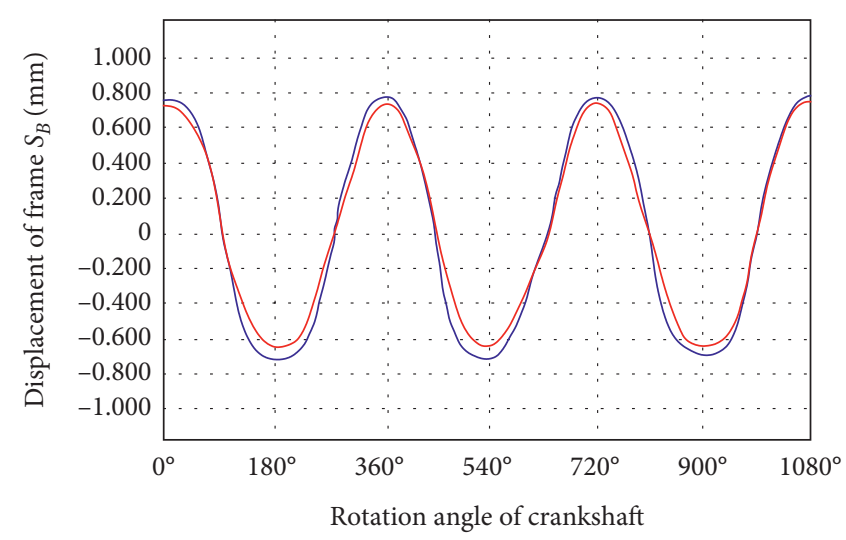

- Experimental

_ Simulated

(a)

(b)

FIGURE 9: Experimental and simulated displacement curves of slider and frame under the motor speed of 1200 rpm: (a) displacement curve of slider; (b) displacement curve of frame. 


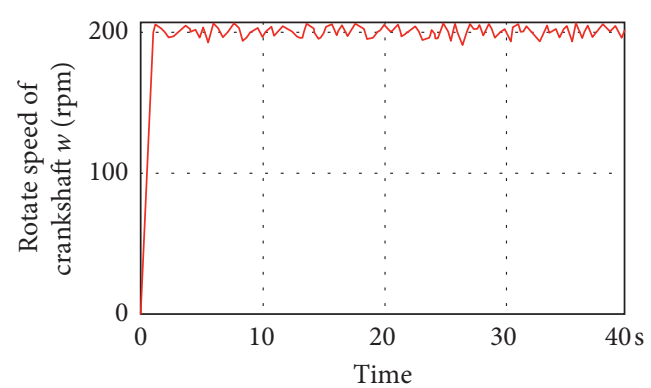

(a)

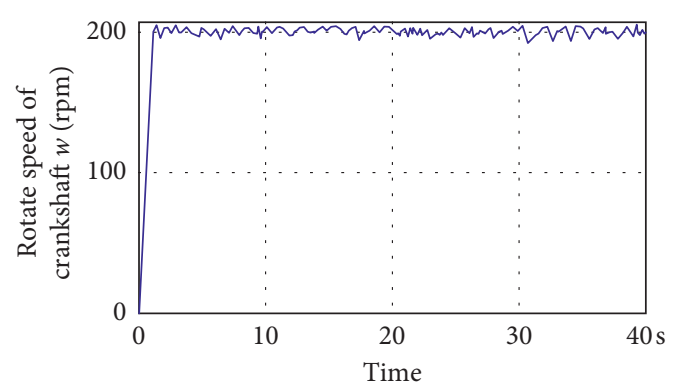

(b)

Figure 10: Crankshaft speed curve under the motor speed of $1000 \mathrm{rpm}$ : (a) experimental crankshaft speed curve; (b) simulated crankshaft speed curve.

TABLE 1: Shape and dimension design of foundation (unit: $\mathrm{m}$ ).

\begin{tabular}{|c|c|c|c|}
\hline \multirow{2}{*}{ Variable } & \multicolumn{3}{|c|}{ Length $\times$ width $\times$ height $/$ diameter $\times$ height } \\
\hline & Rectangular & Square & Circular \\
\hline \multirow{3}{*}{ Shape } & $2.4 \times 3.3 \times 1.2$ & $2.8 \times 2.8 \times 1.2$ & $\emptyset 3.2 \times 1.2$ \\
\hline & $2.4 \times 3.3 \times 1.4$ & $2.8 \times 2.8 \times 1.4$ & $\emptyset 3.2 \times 1.4$ \\
\hline & $2.8 \times 3.7 \times 1.4$ & $3.2 \times 3.2 \times 1.4$ & $\emptyset 3.6 \times 1.4$ \\
\hline \multirow{3}{*}{ Variable depth } & $2.4 \times 3.3 \times 1.2$ & $2.8 \times 2.8 \times 1.2$ & $\emptyset 3.2 \times 1.2$ \\
\hline & $2.4 \times 3.3 \times 1.4$ & $2.8 \times 2.8 \times 1.4$ & $\emptyset 3.2 \times 1.4$ \\
\hline & $2.4 \times 3.3 \times 1.6$ & $2.8 \times 2.8 \times 1.6$ & $\emptyset 3.2 \times 1.6$ \\
\hline \multirow{4}{*}{ Variable area } & $2.4 \times 3.3 \times 1.2$ & $2.8 \times 2.8 \times 1.2$ & $\varnothing 3.2 \times 1.2$ \\
\hline & $2.6 \times 3.5 \times 1.2$ & $3.0 \times 3.0 \times 1.2$ & $\emptyset 3.4 \times 1.2$ \\
\hline & $2.8 \times 3.7 \times 1.2$ & $3.2 \times 3.2 \times 1.2$ & $\varnothing 3.6 \times 1.2$ \\
\hline & $3.0 \times 3.9 \times 1.2$ & $3.4 \times 3.4 \times 1.2$ & $\varnothing 3.8 \times 1.2$ \\
\hline
\end{tabular}

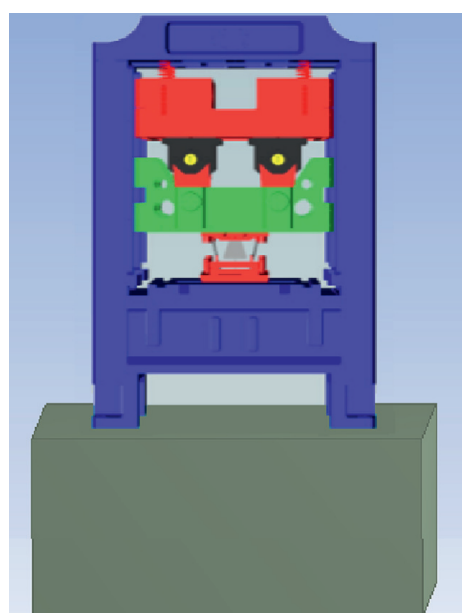

(a)

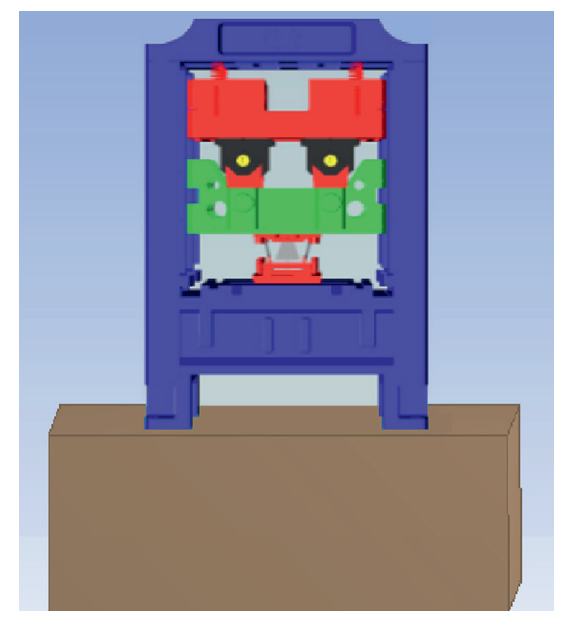

(b)

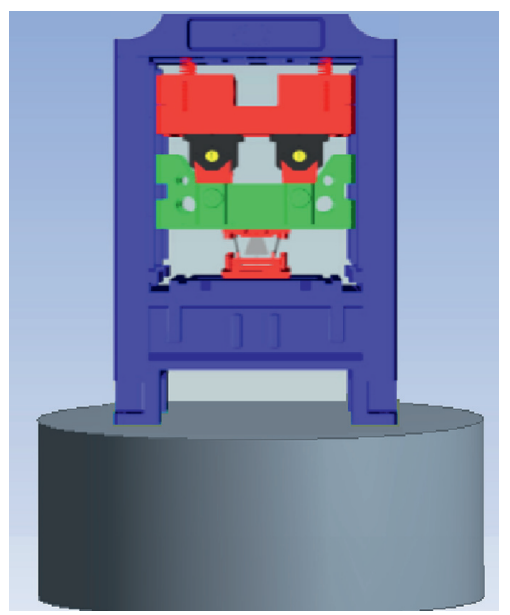

(c)

FIGURE 11: Multidomain model of punch based on different shapes: (a) square foundation; (b) rectangular foundation; (c) circular foundation.

in Table 3. Similar to the situations shown in Table 2, the vibration reduction effect of circular and square foundations is smaller than that of rectangular foundation with the same bottom area and depth. As shown in Table 3, the stiffness and damping of the soil increase when the area of the foundation bottom increases. Because of the difference in the amplitude reduction degree between the frame and the slide, the relative vibration value of the frame and the slide decreases firstly and then increases. It reveals that increasing the bottom area can reduce the vibration of the punching press, while the base area reaches a certain value, and increasing the base area would increase the vibration.

With the increase in the area of the foundation bottom, the amplitude of the frame and the slide decreases, and this is 
TABLE 2: Vibration quantity of punching press under a series of foundations with a variable depth (mm).

\begin{tabular}{|c|c|c|c|c|c|c|c|}
\hline $\begin{array}{l}\text { Length } \times \text { width } \times \text { height } \\
\text { of foundation } \\
(\mathrm{m} \times \mathrm{m} \times \mathrm{m})\end{array}$ & $\begin{array}{l}\text { Stiffness of } \\
\text { subsoil } \\
(\mathrm{N} / \mathrm{m})\end{array}$ & $\begin{array}{c}\text { Damping of } \\
\text { subsoil } \\
(\mathrm{Ns} / \mathrm{m})\end{array}$ & $\begin{array}{l}\text { Vibration } \\
\text { amplitude/ } \\
\text { equilibrium } \\
\text { position of } \\
\text { frame (mm) }\end{array}$ & $\begin{array}{c}\text { Vibration } \\
\text { amplitude/ } \\
\text { equilibrium } \\
\text { position of slider } \\
\text { (mm) }\end{array}$ & $\begin{array}{l}\text { Difference } \\
\text { between } \\
\text { amplitudes of } \\
\text { frame and } \\
\text { slider }(\mathrm{mm})\end{array}$ & $\begin{array}{c}\text { Relative } \\
\text { distance } \\
\text { between } \\
\text { equilibrium } \\
\text { positions of } \\
\text { frame and slider } \\
(\mathrm{mm})\end{array}$ & $\begin{array}{c}\text { Relative } \\
\text { vibration } \\
\text { quantity } \\
(\mathrm{mm})\end{array}$ \\
\hline $2.4 \times 3.3 \times 1.2$ & $660 \times 10^{8}$ & $9.379 \times 10^{5}$ & $0.418 /(-2.512)$ & $0.406 /(-22.482)$ & 0.012 & 0.030 & 0.042 \\
\hline $2.8 \times 2.8 \times 1.2$ & $1.660 \times 10^{8}$ & $9.379 \times 10^{5}$ & $0.449 /(-2.511)$ & $0.435 /(-22.479)$ & 0.014 & 0.032 & 0.046 \\
\hline$\emptyset 3.2 \times 1.2$ & $1.660 \times 10^{8}$ & $9.379 \times 10^{5}$ & $0.458 /(-2.518)$ & $0.439 /(-22.484)$ & 0.019 & 0.034 & 0.053 \\
\hline $2.4 \times 3.3 \times 1.4$ & $1.660 \times 10^{8}$ & $9.0576 \times 10^{5}$ & $0.446 /(-2.664)$ & $0.443 /(-22.638)$ & 0.003 & 0.026 & 0.029 \\
\hline $2.8 \times 2.8 \times 1.4$ & $1.660 \times 10^{8}$ & $9.0576 \times 10^{5}$ & $0.457 /(-2.660)$ & $0.453 /(-22.632)$ & 0.004 & 0.028 & 0.032 \\
\hline$\varnothing 3.2 \times 1.4$ & $1.660 \times 10^{8}$ & $9.0576 \times 10^{5}$ & $0.472 /(-2.667)$ & $0.465 /(-22.636)$ & 0.007 & 0.031 & 0.038 \\
\hline $2.4 \times 3.3 \times 1.6$ & $1.660 \times 10^{8}$ & $8.6147 \times 10^{5}$ & $0.453 /(-2.677)$ & $0.451 /(-22.658)$ & 0.002 & 0.019 & 0.021 \\
\hline $2.8 \times 2.8 \times 1.6$ & $1.660 \times 10^{8}$ & $8.6147 \times 10^{5}$ & $0.464 /(-2.685)$ & $0.461 /(-22.664)$ & 0.003 & 0.021 & 0.024 \\
\hline$\emptyset 3.2 \times 1.6$ & $1.660 \times 10^{8}$ & $8.6147 \times 10^{5}$ & $0.469 /(-2.692)$ & $0.464 /(-22.669)$ & 0.005 & 0.023 & 0.028 \\
\hline
\end{tabular}

TABLE 3: Vibration quantity of punching press under a series of foundations with a variable bottom area (mm).

\begin{tabular}{|c|c|c|c|c|c|c|c|}
\hline $\begin{array}{l}\text { Length } \times \text { width } \times \text { height } \\
\text { of foundation } \\
(\mathrm{m} \times \mathrm{m} \times \mathrm{m})\end{array}$ & $\begin{array}{c}\text { Stiffness of } \\
\text { subsoil } \\
(\mathrm{N} / \mathrm{m})\end{array}$ & $\begin{array}{c}\text { Damping } \\
\text { of subsoil } \\
(\mathrm{Ns} / \mathrm{m})\end{array}$ & $\begin{array}{l}\text { Vibration } \\
\text { amplitude/ } \\
\text { equilibrium } \\
\text { position of } \\
\text { frame (mm) }\end{array}$ & $\begin{array}{c}\text { Vibration } \\
\text { amplitude/ } \\
\text { equilibrium } \\
\text { position of slider } \\
(\mathrm{mm})\end{array}$ & $\begin{array}{l}\text { Difference } \\
\text { between } \\
\text { amplitudes of } \\
\text { frame and } \\
\text { slider }(\mathrm{mm})\end{array}$ & $\begin{array}{c}\text { Relative } \\
\text { distance } \\
\text { between } \\
\text { equilibrium } \\
\text { positions of } \\
\text { frame and slider } \\
(\mathrm{mm}) \\
\end{array}$ & $\begin{array}{c}\text { Relative } \\
\text { vibration } \\
\text { quantity } \\
(\mathrm{mm})\end{array}$ \\
\hline $2.4 \times 3.3 \times 1.2$ & $1.660 \times 10^{8}$ & $9.379 \times 10^{5}$ & $0.418 /(-2.512)$ & $0.406 /(-22.482)$ & 0.012 & 0.030 & 0.042 \\
\hline $2.8 \times 2.8 \times 1.2$ & $1.660 \times 10^{8}$ & $9.379 \times 10^{5}$ & $0.449 /(-2.511)$ & $0.435 /(-22.479)$ & 0.014 & 0.032 & 0.046 \\
\hline$\varnothing 3.2 \times 1.2$ & $1.660 \times 10^{8}$ & $9.379 \times 10^{5}$ & $0.458 /(-2.518)$ & $0.439 /(-22.484)$ & 0.019 & 0.034 & 0.053 \\
\hline $2.6 \times 3.5 \times 1.2$ & $1.8199 \times 10^{8}$ & $9.583 \times 10^{5}$ & $0.394(-2.485)$ & $0.385(-22.461)$ & 0.009 & 0.024 & 0.033 \\
\hline $3.0 \times 3.0 \times 1.2$ & $1.8199 \times 10^{8}$ & $9.583 \times 10^{5}$ & $0.418(-2.489)$ & $0.428(-22.463)$ & 0.010 & 0.026 & 0.036 \\
\hline$\emptyset 3.4 \times 1.2$ & $1.8199 \times 10^{8}$ & $9.583 \times 10^{5}$ & $0.443(-2.494)$ & $0.432(-22.466)$ & 0.011 & 0.028 & 0.039 \\
\hline $2.8 \times 3.7 \times 1.2$ & $1.9850 \times 10^{8}$ & $9.774 \times 10^{5}$ & $0.375(-2.460)$ & $0.369(-22.442)$ & 0.006 & 0.018 & 0.024 \\
\hline $3.2 \times 3.2 \times 1.2$ & $1.9850 \times 10^{8}$ & $9.774 \times 10^{5}$ & $0.386(-2.464)$ & $0.379(-22.444)$ & 0.007 & 0.020 & 0.027 \\
\hline$\varnothing 3.6 \times 1.2$ & $1.9850 \times 10^{8}$ & $9.774 \times 10^{5}$ & $0.397(-2.471)$ & $0.388(-22.447)$ & 0.009 & 0.024 & 0.033 \\
\hline $3.0 \times 3.9 \times 1.2$ & $2.1535 \times 10^{8}$ & $9.961 \times 10^{5}$ & $0.421(-2.527)$ & $0.408(-22.494)$ & 0.013 & 0.033 & 0.046 \\
\hline $3.4 \times 3.4 \times 1.2$ & $2.1535 \times 10^{8}$ & $9.961 \times 10^{5}$ & $0.427(-2.534)$ & $0.413(-22.499)$ & 0.014 & 0.035 & 0.049 \\
\hline$\varnothing 3.8 \times 1.2$ & $2.1535 \times 10^{8}$ & $9.961 \times 10^{5}$ & $0.433(-2.541)$ & $0.417(-22.502)$ & 0.016 & 0.039 & 0.055 \\
\hline
\end{tabular}

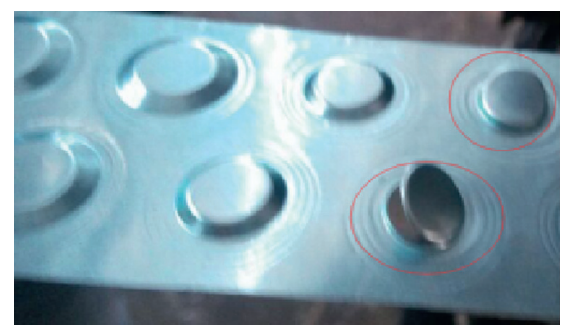

(a)

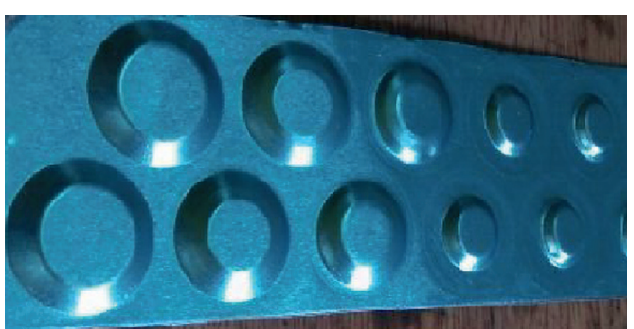

(b)

FiguRE 12: Comparison of drawing results before and after installation foundation with a size of $2.4 \mathrm{~m} \times 3.3 \mathrm{~m} \times 1.6 \mathrm{~m}$ : (a) experimental result without foundation; (b) experimental result with foundation. 
because the foundation mainly acts by changing the area of the soil. When the compression stiffness coefficient of the foundation soil is a constant, the stiffness coefficient of the soil increases with the increase in the bottom area of the foundation. Due to the complexity of the superposition of the stiffness and damping of the punching press system, the difference between the relative vibration amplitude of the frame and the slide increases with the increase in the foundation area, and the difference between the equilibrium positions of these two is not directly proportional to the change in the foundation area.

Large vibration amplitude of the slide and frame will affect the placement and positioning of workpiece, and the relative amplitude of which will affect the final stamping accuracy during the actual forming. On the contrary, the increase in the area and depth of the foundation also brings about the increase in the cost as well as the installation space of the foundation. Therefore, the relationship between the vibration amplitude and the relative vibration of the punching press should be considered in a compromise. When the foundation with a size of $2.4 \mathrm{~m} \times 3.3 \mathrm{~m} \times 1.6 \mathrm{~m}$ in Table 2 was adopted, the amplitude and relative vibration value of the slide and the frame were evenly controlled, and the above indexes were reduced, comparing with the original square foundation; therefore, that foundation size is selected as the optimal size. With the installation of the optimal size foundation, the vibration of the die in the stamping process reduced, and the forming accuracy and quality improved. The drawing defects such as crack (as shown in Figure 12(a)) without the installation of foundation eliminated, and the drawn part without defects (Figure 12(b)) is obtained. Finally, the defect-free stamping production of the fin of air conditioner heat exchanger is realized.

\section{Conclusions}

According to the structure characteristics of the precision high-speed punching press, the multidomain modeling and simulation of which were carried out. The effect of the installation of foundation system on the vibration reduction of the punching press under normal working condition was studied, and the influence of foundation size on the vibration reduction of the punching press was explored. The following conclusions are drawn:

(1) On the basis of multidomain simulation of highspeed punching press, a series of foundation groups with different sizes are designed to study and analyze the influence of the bottom area and depth of the foundation on the vibration reduction. Vibration reduction effect of circular and square foundations is smaller than that of rectangular foundation with the same bottom area and depth.

(2) When the area of the foundation bottom remains constant, the increase in the foundation depth would not change the stiffness of the soil under the foundation, while the damping value of which would be reduced, and the relative vibration value of the frame and the slider will decrease with the increase in the foundation depth.
(3) When the depth of the foundation remains constant, the stiffness and damping of the soil under the foundation increase with the increase in the foundation area. Increasing the area of the foundation bottom within a certain range can reduce the vibration of the punching press. However, when the area of the bottom reaches a certain value, the vibration of the punching press would be increased.

\section{Data Availability}

No data were used to support this study.

\section{Conflicts of Interest}

The authors declare that there are no conflicts of interest regarding the publication of this paper.

\section{Acknowledgments}

The authors would like to thank the funding support from the Produce-learn-research Major Project of Education Ministry in Guangdong (no. 2012B091000128), Project of Guangdong Provincial Key Laboratory of Precision Equipment and Manufacturing Technology (no. PEMT1202), Open Funds of National Engineering Research Center of Near-Net-Shape Forming for Metallic Materials (2016006), Research Project of State Key Laboratory of Mechanical System and Vibration (Project no. MSV201915), National Taipei University of Technology, Shenzhen University Joint Research Program (Project no. 2019010), Natural Science Foundation of Shenzhen University (Grant no. 2019042), and National Natural Science Foundation of China (Grant no. 51705333).

\section{References}

[1] A. Gutés, C. Carraro, and R. Maboudian, "Silver dendrites from galvanic displacement on commercial aluminum foil as an effective SERS substrate," Journal of the American Chemical Society, vol. 132, no. 5, pp. 1476-1477, 2010.

[2] H. Mori, S. Nakamura, F. Ono, K. Kariya, and S. Umezawa, “A study on characteristics of cooling heat transfer of supercritical pressure fluids in a plate heat exchanger," Heat Transfer Engineering, vol. 37, no. 7-8, pp. 659-667, 2015.

[3] S. Elias, "Effect of SSI on vibration control of structures with tuned vibration absorbers," Shock and Vibration, vol. 2019, Article ID 7463031, 12 pages, 2019.

[4] Z. H. Lai, S. B. Wang, G. Q. Zhang, C. L. Zhang, and J. W. Zhang, "Rolling bearing fault diagnosis based on adaptive multiparameter-adjusting bistable stochastic resonance," Shock and Vibration, vol. 2020, Article ID 6096024, 15 pages, 2020.

[5] G. Xue, L. Feng-ge, and L. Xiao-guang, "Monitoring and vibration absorption for dynamic machine foundations," Building Technique Development, vol. 30, no. 7, pp. 32-33, 2003.

[6] J. J. Liu, R. C. Xiao, F. Y. Xei, and W. Liu, "Modal analysis and fault diagnosis of dynamic machine foundation under ambient excitation," Advanced Materials Research, vol. 842, pp. 607-611, 2013. 
[7] T. Zhu and C. L. Chen, "Vibration isolation for frame foundation of a power machinery," Vibration and Impact, vol. 2010, no. 2, pp. 130-133, 2010.

[8] H. Xia, X. Li, and X. Yin, "Analysis of vibration isolation measures for a high-precision equipment platform foundation," Journal of Earthquake Engineering, vol. 40, no. 1, pp. 159-165, 2018.

[9] Z. Zhang, F. Gao, Y. Li, and H. Zhang, "Analysis of tangential nonlinear vibration on machine hydrostatic slide," Shock and Vibration, vol. 2019, Article ID 6024916, 13 pages, 2019.

[10] Z. Zeng, J. Wang, H. Yin, S. Shen, A. A. Shuaibu, and W. Wang, "Experimental investigation on the vibration reduction characteristics of an optimized heavy-haul railway low-vibration track," Shock and Vibration, vol. 2019, Article ID 1539564, 17 pages, 2019.

[11] G. Emrah and E. Atila, "Analysis of free pendulum vibration absorber using flexible multi-body dynamics," Shock and Vibration, vol. 2016, Article ID 3253178, 19 pages, 2016.

[12] X. Xu, H. Tao, and J. Han, "Shock mechanism analysis and simulation of high-power hydraulic shock wave simulator," Shock and Vibration, vol. 2017, Article ID 4361256, 10 pages, 2017.

[13] T. Xu, Q. Xia, X. Wu, J. Ran, F. Gong, and C. Lee, "Influence of hydraulic domain on vibration control and overload prediction of high-speed punching press: multidomain modelling and experiment," Shock and Vibration, vol. 2019, Article ID 8547104, 9 pages, 2019.

[14] China Planning Press, "National standard of the people's republic of China: code for dynamic machine foundation," China Planning Press, Beijing, China, GB 50040-1996, 1996.

[15] P. T. Nguyen, P. D. Trung, and P. H. Hoang, "Effects of foundation mass on dynamic responses of beams subjected to moving oscillators," Journal of Vibroengineering, vol. 22, no. 2, pp. $280-297,2020$.

[16] J. Kumar and V. Boora, "Dynamic response of a machine foundation in combination with spring mounting base and rubber pad," Geotechnical and Geological Engineering, vol. 27, no. 3, pp. 379-389, 2009.

[17] W. B. He, X. K. Li, J. G. Du, Y. Cao, K. Liu, and J. Ma, "Innovative reform in teaching of foundation of machine manufacturing technology course," in Proceedings of the 2019 3rd International Conference on Education, Economics and Management Research (ICEEMR 2019), Singapore, November 2019.

[18] A. Kowalska-Koczwara, F. Pachla, P. Stecz et al., "Vibrationbased damage identification and condition monitoring of metro trains: Warsaw metro case study," Shock and Vibration, vol. 2018, Article ID 8475684, 14 pages, 2018.

[19] Z. Chunjiao, "The application and development of photoelectric sensor," Intelligence Computation and Evolutionary Computation, Advances in Intelligent Systems and Computing, Springer, Berlin, Germany, pp. 671-677, 2013.

[20] H. Xia, X. Li, and X. Yin, "Vibration isolation measures of high precision equipment platform foundation," China Earthquake Engineering Journal, vol. 40, no. 1, pp. 159-165, 2018.

[21] M. A. Hawwa, "Vibration isolation of machine foundations by periodic trenches," Journal of Engineering Mechanics, vol. 124, no. 4, pp. 422-427, 1998.

[22] F. L. Mrad, D. M. L. Machado, G. J. C. Horta, and A. U. Sad, "Optimization of the vibrational comfort of passenger vehicles through improvement of suspension and engine rubber mounting setups," Shock and Vibration, vol. 2018, Article ID 9861052, 9 pages, 2018. 